\title{
Stevens-Johnson Syndrome Due to Cefepime Usage in A Leukemia
}

\section{Patient: A Case Report}

\author{
Lösemi hastasında Sefepim Kullanımına Bağlı Görülen Stevens-Johnson Sendromu: Olgu Sunumu \\ Müfide Okay Özgeyik ${ }^{1}$, Özge Aybı ${ }^{2}$, Hakan Göker ${ }^{3}$ \\ ${ }^{1}$ Eskisehir City Hospital, Department of Hematology, Eskisehir, Turkey \\ ${ }^{2}$ Hacettepe University School of Medicine, Department of Internal Medicine, Ankara, Turkey \\ ${ }^{3}$ Hacettepe University School of Medicine, Department of Hematology, Ankara, Turkey
}

\begin{abstract}
Introduction: Stevens-Johnson syndrome (SJS) and toxic epidermal necrolysis (TEN) are severe mucocutaneous reactions, triggered by medications. Herein, we first reported a relapse acute myeloid leukemia (AML) patient who developed SJS/TEN syndrome after cefepime ( $\beta$-lactam antibiotic) use for neutropenic fever.

Case report: A 50-year-old male patient with AML had $25 \%$ blast rate at bone marrow biopsy in the twelve months after stem cell transplantation. Due to neutropenic fever, cefepime was started. After one day, ceftazidime was started because of some urticaria like lesions. Desquamation of the body was seen 2 days after ceftazidime. Bullous erythema multiforme/SJS/TEN was considered in the differential diagnosis. Cyclosporine $4 \mathrm{mg} / \mathrm{kg}$ per day was started. There was an alleviation in the lesions.

Conclusion: Susceptibility to SJS/TEN has somewhat increased hematological malignancies. Clinicians should be aware of any rashes occurring in the body after any medication, in these patients.
\end{abstract}

Key words: Stevens-Johnson Syndrome, Leukemia, Cefepime.

\section{INTRODUCTION}

Stevens-Johnson syndrome (SJS) and toxic epidermal necrolysis (TEN) are severe mucocutaneous reactions, most commonly triggered by medications, characterized by extensive necrosis and detachment of the epidermis (1). The overall mortality rate among patients with SJS/TEN is approximately $30 \%$ (2). Medications are the major trigger of SJS/TEN, especially allopurinol, antiepileptic drugs and antibacterial sulfonamides antibiotics can be trigger $(3,4)$. The risk of occurrence is limited to the first eight weeks of treatment initiation.

\section{ÖZET}

Giriş: Stevens-Johnson sendromu (SJS) ve toksik epidermal nekrolizis (TEN) ilaçlarla tetiklenen ciddi mukokütanöz reaksiyonlardır. Burada, ilk kez sefepim kullanımına bağlı SJS/TEN sendromu geliştiren relaps akut myeloid lösemi (AML) hastasını sunduk.

Olgu sunumu: 59 yaşında AML tanılı erkek hasta, kök hücre transplantasyonundan 12 ay sonraki kemik iliğinde $\% 25$ blast görüldü. Nötropenik ateş tablosu geliştiren hastaya sefepim tedavisi başlandı. Tedaviden 1 gün sonra, bazıları ürtikeryal lezyonlar geliştiği için seftazidime geçildi. Seftazidinden 2 gün sonra vücutta dökülme şeklinde lezyonlar görüldü. Büllöz eritema multiforme/SJS/TEN ayıııcı tanıda düşünüldü. Siklosporin 4 $\mathrm{mg} / \mathrm{kg} / \mathrm{gün}$ başlandı. Lezyonlar gerileme gösterdi.

Sonuç: Hematolojik kanserlerde SJS/TEN'e yatkınlık artmış durumdadır. Klinisyenler bu hastalarda herhangi bir ilaç verilmesinden sonra vücutta gelişen döküntülerde uyanık olmalıdırlar.

Anahtar Kelimeler: Stevens-Johnson Sendromu, Lösemi, Sefepim

The typical exposure period before reaction onset is four days to four weeks of first continuous use of the drug $(3,4)$. Risk factors for SJS/TEN include human immunodeficiency virus (HIV) infection, genetic factors, underlying immunologic diseases or malignancies, and, possibly, physical factors. Patients with active malignancy have an increased risk of SJS/TEN (3). The risk is highest for patients with hematologic cancers. Herein, we first reported a relapse acute myeloid leukemia (AML) patient who developed SJS/TEN syndrome after cefepime ( $\beta$-lactam antibiotic) use for 
neutropenic fever.

\section{CASE REPORT}

A 50-year-old male patient was diagnosed as acute myeloid leukemia, FLT3 negative, NPM-negative and normal cytogenetic karyotype in 2017 . The patient received an induction regimen of idarubicin $[12 \mathrm{mg} / \mathrm{m} 2$, intravenous (i.v.) 1.,2. and 3. Days] and cytarabine (100 $\mathrm{mg} / \mathrm{m} 2$, i.v., 1-7. Days). Allogeneic stem cell transplantation from identical sibling was performed with busulfan $(0.8 \mathrm{mg} / \mathrm{kg}$, i.v., 4 days) and fludarabine (50mg/m2, i.v., 4 days) (reduced intensive regimen). The numbers of mononuclear cells and CD34+ cells infused were $8.9 \times 10^{8}$ and $7.09 \times 10^{6} / \mathrm{kg}$, respectively. Blast rate was $25 \%$ at bone marrow biopsy in the twelve months after transplantation and chimerism was $69 \%$. The patient received a re-induction regimen of mitoxantrone (12 mg/m2, i.v., 1., 2. and 3. days) and cytarabine (100 mg/m2, i.v., 1-7. days) with relapsed AML. Because of neutropenic fever, meropenem (3x1g, i.v.) was started. Teicoplanin ( $12 \mathrm{mg} / \mathrm{kg} /$ day) was added to therapy due to oral aphthous lesion. ESBL negative E.coli (cefepime sensitive) was positive in blood culture. Meropenem was stopped and cefepime was started. After one day, cefepime was stopped and ceftazidime was started due to fever and some urticaria like lesions. Desquamation of the upper and lower lip was seen 2 days after ceftazidime. There were erythematous targetoid plaques bilateral neck, forehead (Figure 1A). There were erythematous macules with purpuric centers symmetrically on the back, on the abdomen, on the anterior chest, on the upper arms, in the middle of the forearms, inguinal region. Ceftazidime was stopped. The patient was consulted to the dermatology department. Bullous erythema multiforme/SJS/TEN was considered in the differential diagnosis of lesions and punch biopsy was performed. Prognostic score
Prednisolone was started $0.5 \mathrm{mg} / \mathrm{kg} /$ day. One day later, the lesions were progressed and vesicles and bullae and necrosis in the arm skin were seen. Cyclosporine 4 $\mathrm{mg} / \mathrm{kg}$ per day and granulocyte colony stimulating factor (filgrastim) were started. Intravenous immune globulin treatment was not recommended because of a low immunoglobulin A level. Lymphocytic inflammatory infiltrate was present in the superficial dermis at skin biopsy. All antibiotic treatments were stopped. There was an alleviation in the lesions after one week and 10 days (Figure 1B and Figure 1C). The patient was informed that he should not use a beta-lactam group of antibiotics.

\section{DISCUSSION}

A few malignancies were associated with SJS and SJS/TEN or TEN, including multiple myeloma, leukemia, non-Hodgkin's Iymphoma (6). It is not clear whether it is related to malignancy or drug. In the literature, there is an association of SJS/TEN with hematologic malignancies in particular and not malignancy in general [6]. The SJS/TEN is frequent immunocompromised state of cancer. The risk is highest for patients with hematological cancer $(6,7)$. This case was the first case of SJS/TEN depending on the use of cefepime in our knowledge. Neutropenia can be seen one-third of patients and correlated with poor prognosis. There are no universally accepted diagnostic criteria for SJS/TEN. The clinicians should be alert if erythematous macules, targetoid lesions, rapid progression of lesions, a suggestive history of drug exposure (8). There is a prognostic scoring system (SCORTEN score) based on age of patient, malignancy, body surface area, laboratory variables for SJS/TEN (5). This patient's SCORTEN score was 2. (SCORTEN score) was 2 (5). 

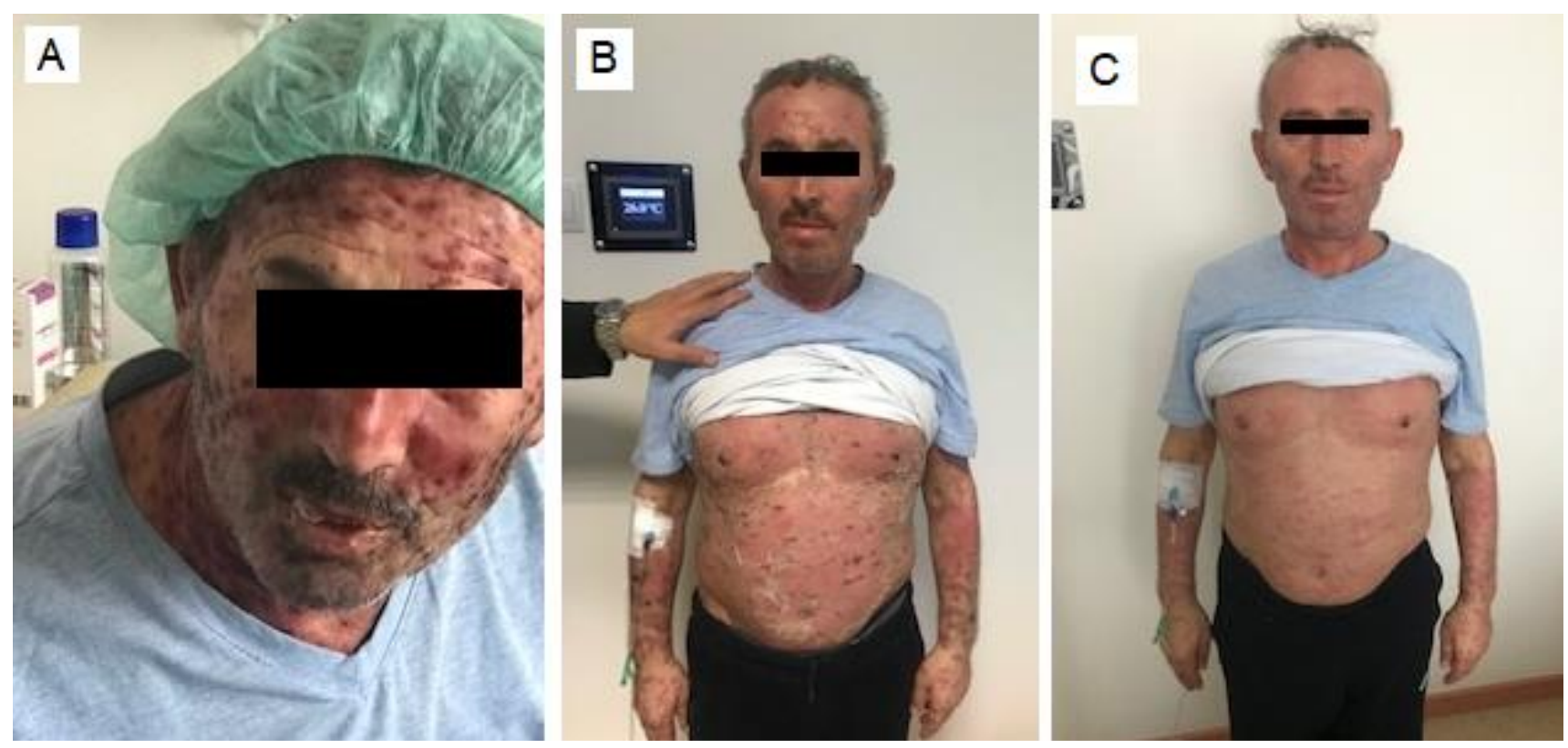

Figure 1A. Day 2 after cefepime, the lesions of patient's face. 1B. Day 6 after cyclosporin treatment. 1C. Day 10 after cyclosporin treatment.

In the treatment, there are no established therapies (9). Different immunosuppressive or immunomodulating therapies have been used in clinical practice, including systemic corticosteroids, intravenous immune globulin (IVIG), cyclosporine. When cyclosporine given at the dose of 3 to $5 \mathrm{mg} / \mathrm{kg}$ per day may slow the progression of SJS/TEN (10). The mechanism of action of cyclosporine in SJS/TEN involves the inhibition of $T$ cell activation, thus preventing the production and release by cytotoxic $T$ cells and natural killer cells of cytokines, which play a critical role in the pathogenesis. The lesions of the patient began to recover rapidly after adding cyclosporin to the treatment.

Patients who survive SJS/TEN attributed to a medication must be educated about future avoidance. Proper information should be inscribed on a medical information bracelet or necklace and worn at all times. In conclusion, susceptibility to SJS/TEN has somewhat increased hematological malignancies (7). Clinicians should be aware of any rashes occurring in the body after any medication, in these patients.
Informed Consent: Informed consent was taken from the patient.

Conflict of Interest: The authors declare that they have no conflict of interest.

Funding: No funding was taken for this study.

\section{REFERENCES}

1. Stern RS, Divito SJ. Stevens-Johnson Syndrome and Toxic Epidermal Necrolysis: Associations, Outcomes, and Pathobiology-Thirty Years of Progress but Still Much to Be Done. J Invest Dermatol. 2017 May;137(5):1004-8.

2. Sekula $P$, Dunant $A$, Mockenhaupt $M$, et al. Comprehensive survival analysis of a cohort of patients with Stevens-Johnson syndrome and toxic epidermal necrolysis. J Invest Dermatol. 2013 May;133(5):1197-204.

3. Mockenhaupt M, Viboud C, Dunant A, et al. Stevens-Johnson syndrome and toxic epidermal necrolysis: assessment of medication risks with emphasis on recently marketed drugs. The EuroSCAR-study. J Invest Dermatol. 2008 Jan;128(1):35-44.

4. Halevy S, Ghislain P-D, Mockenhaupt M, et al. Allopurinol is the most common cause of Stevens-Johnson syndrome and toxic epidermal necrolysis in Europe and Israel. J Am Acad Dermatol. 2008 Jan;58(1):25-32.

5. Bastuji-Garin S, Fouchard N, Bertocchi M, Roujeau JC, Revuz J, Wolkenstein P. SCORTEN: a severity-of-illness score for toxic epidermal necrolysis. J Invest Dermatol. 2000 Aug;115(2):14953.

6. Hsu DY, Brieva J, Silverberg NB, Silverberg JI. Morbidity and Mortality of Stevens-Johnson Syndrome and Toxic Epidermal 
Necrolysis in United States Adults. J Invest Dermatol. 2016 Jul;136(7):1387-97.

7. Frey N, Jossi J, Bodmer M, et al. The Epidemiology of StevensJohnson Syndrome and Toxic Epidermal Necrolysis in the UK. J Invest Dermatol. 2017 Jun;137(6):1240-7.

8. Schwartz RA, McDonough PH, Lee BW. Toxic epidermal necrolysis: Part II. Prognosis, sequelae, diagnosis, differential diagnosis, prevention, and treatment. J Am Acad Dermatol. 2013 Aug;69(2):187.e1-16; quiz 203-4.

9. Schneck J, Fagot JP, Sekula P, Sassolas B, Roujeau JC, Mockenhaupt M. Effects of treatments on the mortality of
Stevens-Johnson syndrome and toxic epidermal necrolysis: A retrospective study on patients included in the prospective EuroSCAR Study. J Am Acad Dermatol. 2008 Jan;58(1):33-40.

10. González-Herrada C, Rodríguez-Martín S, Cachafeiro L, et al. Cyclosporine Use in Epidermal Necrolysis Is Associated with an Important Mortality Reduction: Evidence from Three Different Approaches. J Invest Dermatol. 2017 Oct;137(10):2092-100.

Cite as: Okay Özgeyik M, Aybı Ö, Göker H. Stevens-Johnson Syndrome Due to Cefepime Usage in A Leukemia Patient: A Case. Eskisehir Med J. 2021;2(2):135-8. 